\title{
BRPKM
}

\author{
Buletin Riset Psikologi dan Kesehatan Mental \\ http://e-journal.unair.ac.id/index.php/BRPKM \\ e-ISSN: 2776-1851
}

ARTIKEL PENELITIAN

\section{Hubungan Strategi Koping dan Kesejahteraan Psikologis pada Remaja yang Mengalami Kekerasan dalam Rumah Tangga}

\author{
TAZAKKA PUTRI OKTOJI \& HERDINA INDRIJATI* \\ Fakultas Psikologi Universitas Airlangga
}

\begin{abstract}
ABSTRAK
Kekerasan dalam rumah tangga diketahui masih marak terjadi di Indonesia dan korban terbanyak ialah remaja. Kekerasan dalam rumah tangga mengakibatkan banyak dampak negatif, salah satunya ialah kesejahteraan psikologis. Penelitian ini bertujuan untuk mengetahui hubungan antara strategi koping dan kesejahteraan psikologis pada remaja yang mengalami kekerasan dalam rumah tangga (KDRT). Partisipan dari penelitian ini ialah 45 remaja berusia 14-17 tahun yang mengalami kekerasan dalam rumah tangga (KDRT). Alat ukur yang digunakan ialah skala BriefCOPE dan Scales of Psychological WellBeing dengan menggunakan program IBM SPSS 22.0 for Windows. Berdasarkan analisis yang telah dilakukan, diperoleh hasil koefisien korelasi sebesar 0,637 pada kedua variabel. Pada dimensi ProblemFocused Coping diperoleh koefisien korelasi sebesar 0,187. Emotion-Focused Coping sebesar 0,237 dan Dysfunctional Coping sebesar 0,537 terhadap kesejahteraan psikologis. Hal ini menunjukkan bahwa semakin tinggi penggunaan strategi koping maka semakin tinggi pula kesejahteraan psikologis pada remaja korban kekerasan dalam rumah tangga (KDRT).
\end{abstract}

Kata kunci: kekerasan dalam rumah tangga (kdrt), kesejahteraan psikologis, remaja, strategi koping

\begin{abstract}
Domestic violence is known to be prevalent in Indonesia and the largest number of victims are adolescent. Domestic violence has many negative impacts, one of them is psychological well-being. This study aims to determine the relationship between coping strategies and psychological well-being in adolescents who experienced domestic violence. Participants of this study were 45 adolescents aged 1417 years who experienced domestic violence. The measuring instrument used is the COPE Brief scale and the Scales of Psychological Well-Being using the IBM SPSS 22.0 for Windows program. Based on the analysis that has been done, the correlation coefficient is 0.637 for both variables. Correlation coefficient for problem-focused coping dimension is 0.187, Emotion-Focused Coping is 0.237 and Dysfunctional Coping is 0.537 on psychological well-being. This shows that the higher the use of coping strategies, the higher the psychological well-being of adolescent victims of domestic violence.
\end{abstract}

Keywords: adolescents, coping strategies, domestic violence, psychological well-being

Buletin Penelitian Psikologi dan Kesehatan Mental (BRPKM), 2021, Vol. 1(1), 560-568

*Alamat korespondensi: Fakultas Psikologi Universitas Airlangga, Kampus B Universitas Airlangga Jalan

Airlangga 4-6 Surabaya 60286. Surel: herdina.indrijati@psikologi.unair.ac.id 
Naskah ini merupakan naskah dengan akses terbuka dibawah ketentuan the Creative Common Attribution License (CC-BY-4.0) (http://creativecommons.org/licenses/by/4.0), sehingga penggunaan, distribusi, reproduksi dalam media apapun atas artikel ini tidak dibatasi, selama sumber aslinya disitir dengan baik.

\section{PENDAHULUAN}

Masa remaja adalah masa transisi dari anak-anak menuju masa dewasa yang melibatkan perubahan biologis, kognitif dan sosio-emosional (Santrock, 2014). Remaja tidak hanya menghadapi perubahan secara biologis, kognitif, dan sosio-emosional, tetapi juga tugas-tugas perkembangan yang harus diselesaikan. Hall (1916 dalam Papalia dkk., 2009) mengungkapkan bahwa remaja yang berusaha beradaptasi dengan perubahan tubuhnya dan tuntutan dari orang dewasa akan menuntun mereka pada masa badai dan stres yang dapat menghasilkan konflik antar generasi. Perubahan yang dialami dan potensi konflik yang dihadapi dapat memengaruhi kondisi psikologis pada remaja, seperti kesejahteraan psikologis.

Kesejahteraan psikologis secara umum mengacu pada pengalaman dan fungsi psikologis yang optimal (Ryan \& Deci, 2001). Ryff (1989) mendefinisikan kesejahteraan psikologis dalam perspektif eudaimonik sebagai integrasi dari konsep kesehatan mental, psikologi klinis dan perkembangan yang berkaitan dengan fungsi psikologis positif pada manusia, yaitu pengoptimalan potensi pada manusia. Individu secara umum dianggap memiliki kesejahteraan psikologis yang optimal jika memiliki penerimaan aspek baik dan buruk dari diri sendiri, memiliki hubungan yang positif dengan orang lain, dapat menentukan nasib sendiri dan mandiri, memiliki kemampuan untuk mengelola lingkungannya, memiliki tujuan hidup, serta dapat memaknai hidup dan melihat diri sebagai individu yang terus berkembang (Ryff, 1989). Gao \& McLellan (2018) mengungkapkan bahwa remaja dan dewasa memiliki aspek fungsi positif yang hampir sama karena jika dilihat secara teoritis, remaja berada pada periode transisi dari anakanak menuju masa dewasa.

Kesejahteraan psikologis remaja berpotensi mengalami hambatan jika aspek perkembangannya tidak tercapai atau mengalami kendala, terutama aspek perkembangan konsep diri dan perkembangan emosi. Apabila remaja hidup dalam kondisi yang kurang ideal, maka kesejahteraan psikologis mereka berpotensi menjadi lebih buruk. Kondisi yang kurang ideal bisa seperti lingkungan yang tak dapat mendukung perubahan dan perkembangannya. Lingkungan menjadi faktor penting yang memengaruhi remaja. Hal ini sesuai dengan apa yang diungkapkan Santrock (2014) bahwa interaksi antara faktor genetik dan lingkungan akan memengaruhi perkembangan manusia.

Keluarga sebagai lingkungan di mana anak tumbuh dan berkembang akan memengaruhi bagaimana anak bertingkah laku. Offer (2002 dalam Papalia dkk., 2009) mengungkapkan bahwa anak yang dibesarkan dalam keluarga yang positif akan melewati masa remajanya tanpa masalah yang serius dan ketika dewasa dapat menjalani hidupnya dengan baik. Namun pada kenyataannya, tidak semua keluarga dapat berfungsi secara optimal. Keluarga yang disfungsional adalah keluarga yang mengalami konflik, kekerasan, hingga adanya anggota yang berperilaku buruk, di mana hal-hal tersebut terjadi berulang kali (M.Senthil dkk., 2014). M.Senthil dkk (2014) juga mengungkapkan bahwa keluarga yang disfungsional bisa disebabkan karena adiksi terhadap alkohol atau adiksi lainnya, penyalahgunaan zat, penyakit mental, hingga kekerasan dalam rumah tangga (KDRT).

Kekerasan yang terjadi dalam lingkup rumah tangga memiliki istilah lain, yaitu kekerasan domestik. Kekerasan domestik didefinisikan sebagai perilaku dari hubungan intim orang dewasa yang

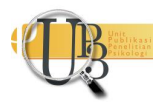


menyebabkan kerugian fisik, psikologis, atau seksual, dan dapat memengaruhi anak-anak (Moreno dkk., 2006). Kekerasan dalam rumah tangga (KDRT) merupakan masalah serius di Indonesia yang ditandai dengan terbentuknya lembaga-lembaga perlindungan korban dan undang-undang yang mengatur kekerasan dalam rumah tangga (KDRT). Menurut Undang-Undang Republik Indonesia nomor 23 tahun 2004 tentang penghapusan kekerasan dalam rumah tangga (KDRT), pasal 1 ayat 1 menyebutkan bahwa kekerasan rumah tangga adalah setiap perbuatan terhadap seseorang terutama perempuan, yang berakibat timbulnya kesengsaraan atau penderitaan secara fisik, seksual, psikologis, dan/atau penelantaran rumah tangga termasuk ancaman untuk melakukan perbuatan, pemaksaan, atau perampasan kemerdekaan secara melawan hukum dalam lingkup rumah tangga. Demikian juga pada pasal 2 ayat 1 Undang-Undang Republik Indonesia nomor 23 tahun 2004 yang menyebutkan bahwa lingkup rumah tangga meliputi, (a) Suami, isteri, dan anak (termasuk anak angkat dan anak tiri); (b) Orang-orang yang mempunyai hubungan keluarga dengan orang sebagaimana dimaksud dalam huruf a karena hubungan darah, perkawinan, persusuan, pengasuhan, dan perwalian, yang menetap dalam rumah tangga (mertua, menantu, ipar dan besan); dan/atau (c) Orang yang bekerja membantu rumah tangga dan menetap dalam rumah tangga tersebut (Pekerja Rumah Tangga).

Faktanya kekerasan pada remaja dalam lingkup keluarga masih banyak terjadi di Indonesia. Berdasarkan SIMFONII-PPA (Sistem Informasi Online Perlindungan Perempuan dan Anak) yang penulis akses pada tahun 2019 menunjukkan bahwa pada periode data kasus tahun 2019 terdapat 5.435 kasus. Jenis kekerasan yang paling sering dialami korban ialah kekerasan fisik dengan jumlah kasus 4.428 dan korban berdasarkan usia terbanyak sejumlah 3.001 kasus pada usia 13-17 taun. Hingga bulan September 2020, SIMFONII-PPA (Sistem Informasi Online Perlindungan Perempuan dan Anak) mencatat 10.364 total kasus kekerasan di Indonesia. Kasus kekerasan yang terjadi dalam lingkup rumah tangga meningkat menjadi 6.099 kasus. Korban yang mengalami kekerasan terbanyak masih dipegang oleh remaja berusia 13-17 tahun dengan total 3.674 kasus. Jenis kekerasan yang paling sering dialami korban pada tahun 2020 adalah kekerasan seksual dengan total 4.207 kasus. Terdapat kemungkinan terjadi peningkatan data kekerasan anak dalam ranah rumah tangga melihat data sebelumnya yang terjadi peningkatan.

Kekerasan dalam rumah tangga (KDRT) dapat berakibat buruk bagi remaja, baik dalam jangka pendek maupun panjang. Hal ini sejalan dengan Shannon (2009) yang telah merangkum dan mengkategorikan 3 permasalahan anak berkaitan dengan kekerasan dalam rumah tangga (KDRT), yaitu: (1) Permasalahan perilaku, sosial dan emosional, (2) Permasalahan sikap dan kognitif, (3) Permasalahan jangka panjang seperti depresi saat dewasa. Kekerasan dalam rumah tangga (KDRT) yang merupakan konflik dalam keluarga juga berdampak pada kesejahteraan psikologis remaja. Nastasi \& Borja (2016) mengungkapkan bahwa salah satu hal yang dapat memengaruhi kesejahteraan psikologis remaja ialah konflik keluarga. Hal ini sejalan dengan penelitian yang dilakukan Cynthia dkk., (2018) yang mengungkapkan bahwa terdapat resiko besar untuk perilaku nakal atau kejahatan dan kesejahteraan psikologis yang buruk pada remaja yang mengalami pelecehan fisik, psikologis dan sosial, penolakan atau pengabaian dari orang tua atau orang tua asuh.

Kesejahteraan psikologi dipengaruhi oleh beberapa faktor, seperti usia, gender, budaya, perbedaan kelas atau status sosial-ekonomi, peristiwa atau pengalaman dalam hidup dan sejarah hidup (Ryff \& Singerb, 1996). Selain itu, lingkungan sosial dan faktor individual dapat memengaruhi kesejahteraan psikologis remaja. Hal ini sejalan dengan Nastasi \& Borja (2016) yang menunjukkan bahwa kesejahteraan psikologis remaja dipengaruhi oleh faktor individu dan faktor sosial budaya. Faktor individual terdiri dari kompetensi yang bernilai budaya, kerentanan pribadi, dan sumber daya pribadi, sedangkan faktor kultural terdiri dari stresor sosial budaya, sumber daya dari sosial budaya, norma 
budaya, agen sosialisasi, dan praktik sosialisasi (Nastasi \& Borja, 2016). Pokok-pokok dari faktor individual mencakup riwayat personal, karakteristik diri dan kemampuan diri, termasuk kemampuan koping (Nastasi \& Borja, 2016).

Koping adalah usaha individu secara perilaku dan kognitif yang terus berubah untuk mengatasi tuntutan eksternal maupun internal yang dinilai dapat melebihi sumber daya individu tersebut (Lazarus \& Folkman, 1984). Lazarus \& Folkman (1984) mengungkapkan bahwa strategi koping menjadi mekanisme penting ketika menghadapi stres untuk mempertahankan kesejahteraan psikologis individu. Stres psikologis adalah hubungan antara individu dan lingkungannya, dimana hubungan tersebut diniliai dapat membebani atau melebihi sumber daya yang dimiliki individu serta berpotensi membahayakan kesejahteraannya (Lazarus \& Folkman, 1984). Kekerasan dalam rumah tangga (KDRT) adalah contoh pengalaman hidup yang dapat dipersepsi negatif, sehingga dapat menyebabkan stres dan berpotensi membahayakan kesejahteraan psikologis individu. Hal ini sejalan dengan Rode dkk., (2019) yang dalam penelitiannya menyebutkan bahwa kekerasan dalam keluarga dapat menimbulkan stres dan terdapat kemungkinan bagi individu untuk meresponnya dengan koping maladaptif yang berakibat munculnya permasalahan internal maupun eksternal.

Berdasarkan penelitian yang dilakukan oleh Freire dkk., (2016), terdapat hubungan antara strategi koping dan kesejahteraan psikologis pada mahasiswa dalam konteks akademik. Penelitian lainnya berkaitan dengan strategi koping dan kesejahteraan psikologis dilakukan oleh Mayordomo-Rodríguez dkk., (2015) pada dewasa muda dengan rentang usia 18-34 tahun, menujukkan bahwa koping yang berfokus pada masalah akan memprediksi kesejahteraan psikologis yang baik dan koping yang berfokus pada emosional akan memprediksi kesejahteraan psikologis yang buruk. Di Indonesia, penelitian mengenai strategi koping pada korban KDRT dilakukan secara kualitatif oleh Zafirah \& Indriana (2016) yang menunjukan bahwa subjek menggunakan strategi koping maladaptif seperti penghindaran diri dari masalah, percobaan bunuh diri, dan mengonsumsi alkohol ketika mengalami kekerasan dalam rumah tangga (KDRT). Subjek juga menyimpan perasaan benci, dendam, dan memengaruhi nilai akademiknya di sekolah.

Penelitian mengenai strategi koping dan kesejahteraan psikologis pada remaja yang mengalami permasalahan keluarga berupa kekerasan dalam rumah tangga (KDRT) ditemukan dalam penelitian kualitatif dan tidak dapat digeneralisasi pada remaja korban KDRT lainnya. Oleh karena itu peneliti ingin mengetahui apakah ada hubungan antara strategi koping dan kesejahteraan psikologis pada remaja di Indonesia yang mengalami kekerasan dalam rumah tangga (KDRT).

\section{Desain Penelitian}

\section{METODE}

Penelitian ini menggunakan teknik pengumpulan data kuantitatif dengan metode pengumpulan data berupa survei. Penelitian yang dilakukan peneliti merupakan penelitian explanatory research karena peneliti ingin mengetahui penjelasan dari hubungan antara variabel yang akan diteliti, yaitu variabel strategi koping dan kesejahteraan psikologis. Hipotesis dari penelitian ini ialah terdapat hubungan antara strategi koping dan kesejahteraan psikologis pada remaja yang mengalami kekerasan dalam rumah tangga (KDRT). 


\section{Partisipan}

Partisipan dalam penelitian ini ialah 45 remaja dengan rentang usia 14-17 tahun di Indonesia yang pernah mengalami kekerasan dalam rumah tangga (KDRT) seperti kekerasan fisik, emosional, seksual, dan/atau pengabaian $\left(M_{\text {usia }}=15,51 ; S D_{\text {usia }}=1,100 ; 80\right.$ persen perempuan).

Teknik pengambilan sampel yang akan dilakukan peneliti adalah teknik nonprobability sampling berupa purposive sampling. Ukuran sampel partisipan ditentukan dengan menggunakan program G*power. Statistical power yang digunakan ialah 0.8 dan least detectable effect size ialah 0,5 sehingga didapatkan jumlah minimal partisipan yaitu 29 partisipan.

\section{Pengukuran}

Strategi koping. Skala strategi koping yang digunakan menggunakan skala Brief COPE milik Carver (1997). Skala Brief Cope terdiri dari 28 aitem dengan rincian: dimensi koping yang berfokus pada masalah 6 aitem, koping yang berfokus pada emosi 12 aitem, dan koping yang disfungsional 10 aitem. Dalam alat ukur Brief Cope tidak memiliki aitem yang dibalik/unfavorable aitem. Penilaian strategi koping dilakukan dengan menjumlahkan skor total dengan menggunakan Brief COPE (Carver, 1997), di mana semakin tinggi total skor maka semakin mempresentasikan beragam jenis koping yang digunakan. Dihitung menggunakan skala likert dari 1 hingga 4: (1) Belum pernah, (2) Kadang-kadang, (3) Sering, (4) Sangat sering. Perhitungan reliabilitas menggunakan alpha stratified atau alfa berstrata dengan nilai $=.637$ yang termasuk kategori tinggi.

Kesejahteraan psikologis. Skala kesejehteraan psikologis yang digunakan dalam penelitian ini mengacu pada Scales of Psychological Well-Being Ryff (1989) yang sudah diadaptasi dan divalidasi oleh Azhari (2019). Alat ukur kesejahteraan psikologis disusun dalam 6 dimensi psychological well-being Ryff, yaitu dimensi self-acceptance, autonomy, enviromental mastery, positive relation with other, purpose in life, dan personal growth. Alat ukur ini memilik 42 aitem dengan rincian 7 aitem tiap dimensi. Hasil uji reliabilitas yang dilakukan oleh Azhari (2019) menunjukkan angka $\alpha=.880$ yang termasuk dalam kategori tinggi pada populasi remaja. Penilaian tersebut dihitung dengan menjumlahkan total skor pada keseluruhan indikator kesejahteraan psikologis. Dihitung menggunakan skala likert dari 1 hingga 4: (1) Sangat setuju, (2) Setuju, (3) Tidak setuju, (4) Sangat tidak setuju.

Uji Asumsi. Uji asumsi yang dilakukan ialah uji normalitas dan linearitas. Uji normalitas dilakukan dengan menggunakan teknik Saphiro-Wilk yang menunjukkan bahwa kedua variabel berdistribusi normal karena nilai signifikansi $\mathrm{p}>0,05$. Uji linearitas menunjukkan adanya hubungan yang linear karena memiliki nilai signifikansi $\mathrm{p}<0,05$.

\section{Analisis Data}

Teknik analalisis data yang digunakan ialah uji korelasi pearson menggunakan bantuan program IBM SPSS 22.0 for Windows. Uji Korelasi digunakan untuk mengetahui kekuatan dan arah hubungan dari kedua variabel, sedangkan uji Korelasi Parsial digunakan untuk mengetahui hubungan antara masingmasing jenis strategi koping dengan kesejahteraan psikologis.

\section{HASIL PENELITIAN}

Partisipan penelitian ini ialah 45 remaja yang mengalami kekerasan dalam rumah tangga. Partisipan dikelompokkan berdasarkan usia, jenis kelamin dan kekerasan yang paling sering dialami. Berdasarkan

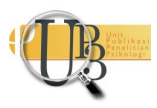


gambaran umum usia responden, maka dapat diketahui bahwa terdapat 10 subjek $(22,2 \%)$ berumur 14 tahun, 13 subjek $(28,9 \%)$ berumur 15 tahun, 11 subjek $(24,4 \%)$ berumur 16 tahun dan 11 subjek $(24,4 \%)$ berumur 17 tahun. Berdasarkan gambaran umum jenis kelamin responden, maka dapat diketahui terdapat 9 subjek (20\%) berjenis kelamin laki-laki dan 36 subjek (80\%) berjenis kelamin perempuan. Berdasarkan gambaran umum KDRT yang paling sering dialami oleh partisipan, maka dapat diketahui bahwa terdapat 5 subjek $(11,1 \%)$ yang paling sering mengalami kekerasan fisik, 38 subjek $(84,4 \%)$ yang mengalami kekerasan emosional, 2 subjek $(4,4 \%)$ yang mengalami pengabaian dan tidak ada yang mengalami kekerasan seksual.

Berdasarkan analisis deskriptif yang dilakukan, maka diperoleh nilai rata-rata variabel kesejahteraan psikologis ialah 117,9556 dan 61,6222 untuk variabel strategi koping. Nilai minimum untuk variabel kesejahteraan psikologis ialah 100, sedangkan untuk variabel strategi koping ialah 45. Nilai maksimum untuk variabel kesejahteraan psikologis ialah 133 dan 75 untuk variabel strategi koping. Range atau jangkauan data pada variabel kesejahteraan psikologis ialah 33 dan 30 untuk variabel strategi koping. Nilai skewness yang ditunjukkan variabel kesejahteraan psikologis ialah -0,118 dan -0,432 pada variabel strategi koping. Nilai kurtosis pada variabel kesejahteraan psikologi ialah -0,689 dan -0,056 pada variabel strategi koping.

Berdasarkan hasil uji korelasi pearson yang dilakukan diketahui bahwa strategi koping berkorelasi positif dan memiliki kekuatan hubungan yang besar $(\mathrm{r}(45)=0,637 ; p=0,000)$ dengan kesejahteraan psikologis pada remaja korban KDRT. Berdasarkan hasil uji korelasi parsial pada tiap dimensi koping terhadap kesejahteraan psikologis menunjukkan hasil sebagai berikut: (1) Problem-Focused Coping dan kesejahteraan psikologis memiliki korelasi yang positif dan cenderung kecil $\operatorname{lr}(45)=0,181 ; p=0,050)$, (2) Emotion-Focused Coping dan kesejahteraan psikologis menunjukkan korelasi yang positif dan cenderung kecil (r(45)=0,237; p=0,001), (3) Dysfunctional Coping dengan kesejahteraan psikologis memiliki korelasi yang positif dan cenderung besar $(\mathrm{r}(45)=0,537 ; p=0,000)$.

\section{DISKUSI}

Penelitian ini bertujuan untuk mencari tahu apakah terdapat hubungan antara strategi koping dan kesejahteraan psikologis pada remaja dalam konteks kekerasan dalam rumah tangga (KDRT). Hasil uji korelasi menunjukkan bahwa terdapat hubungan antara strategi koping dengan kesejahteraan psikologis pada remaja yang mengalami kekerasan dalam rumah tangga (KDRT). Hubungan bersifat kuat dan memiliki arah yang positif. Hasil penelitian korelasi ini sejalan dengan Nastasi \& Borja (2016) yang menyatakan bahwa strategi koping memiliki hubungan dengan kesejahteraan psikologis, sebagai faktor yang dapat memengaruhi. Hasil penelitian ini juga sejalan dengan penelitian terdahulu yang dilakukan oleh Freire dkk (2016) pada populasi mahasiswa, di mana penelitian tersebut menunjukkan adanya hubungan yang signifikan antara strategi koping dan kesejahteraan psikologis.

Hasil analisis korelasi parsial menunjukkan bahwa terdapat hubungan dengan arah yang positif pada Problem-Focused Coping, Emotion-Focused Coping dan Dysfunctional Coping terhadap kesejahteraan psikologis. Berdasarkan penelitian terdahulu terdapat perbedaan mengenai arah hubungan antar variabel. Dalam penelitian yang dilakukan oleh Mayordomo-Rodríguez dkk., (2015), Problem-Focused Coping memiliki hubungan yang positif dengan kesejahteraan psikologis dan Emotion-Focused Coping memiliki hubungan yang negatif dengan kesejahteraan psikologis. Perbedaan ini mungkin disebabkan oleh variabel-variabel lain yang memengaruhi kesejahteraan psikologis maupun pemilihan strategi koping yang digunakan. Lazarus \& Folkman (1984) mengungkapkan bahwa strategi koping yang dilakukan tiap individu bisa berbeda dengan mempertimbangkan faktor personal dan situasionalnya. 
Kekuatan korelasi dari ketiga jenis dimensi strategi koping menunjukkan hasil yang berbeda terhadap kesejahteraan psikologis. Variabel strategi koping jenis Problem-Focused Coping dan Emotion-Focused Coping memiliki kekuatan hubungan yang kecil terhadap kesejahteraan psikologis, sedangkan Dysfunctional Coping memiliki kekuatan hubungan yang besar. Meskipun Dyfunctional Coping merupakan respon koping yang dikategorikan kurang berguna bagi individu, namun Wortman \& Lehman (1985 dalam Carver dkk., 1989) mengungkapkan bahwa faktor individu, situasi tertentu dan periode penggunaan strategi dapat memengaruhi keberhasilan fungsi strategi koping yang digunakan.

Jika meninjau kekuatan hubungan tiap jenis strategi koping terhadap kesejahteraan psikologis, maka dapat diketahui bahwa penggunaan berbagai macam strategi koping yang dilakukan oleh remaja tetap menghasilkan kesejahteraan psikologis yang rendah hingga sedang. Hal ini dapat mengindikasikan bahwa penggunaan strategi koping tidak efektif atau adaptif bagi remaja ketika dihadapkan dengan konteks KDRT. Carver (2003 dalam Monzani dkk., 2015) mengungkapkan bahwa respon koping yang adaptif bagi individu adalah koping yang mengarahkan individu untuk mencapai tujuan yang diinginkan dan membuat kemajuan dalam hidupnya. Selain itu, terdapat kemungkinan adanya ekspektasi yang rendah terhadap hasil dari koping yang dilakukan sejak awal penilaian situasi, sehingga strategi koping apapun yang dipilih akan berdampak rendah pada kesejahteraan psikologis remaja. Carver (1989) juga mengungkapkan bahwa behavioral disengagement yang termasuk dalam Dysfunctional Coping biasanya dilakukan ketika individu berkespektasi hasil koping yang buruk. Hasil dari penelitian ini sejalan dengan Freire dkk (2016) yang mengungkapkan bahwa kesejahteraan psikologis yang rendah berhubungan dengan penggunaan strategi koping yang disfungsional seperti menyalahkan diri sendiri, mengabaikan masalah, dan memikirkan hal lain selain masalah tersebut.

Kelemahan dari penelitian ini ialah peneliti hanya meneliti faktor strategi koping sebagai variabel X, sehingga peneliti tidak mengetahui faktor-faktor lain yang mungkin mempunyai pengaruh pada kesejahteraan psikologis remaja. Selain itu, peneliti tidak meneliti lebih jauh faktor-faktor yang memengaruhi pemilihan strategi koping yang bervariasi pada subjek penelitian.

\section{SIMPULAN}

Berdasarkan hasil penelitian yang telah dilakukan, maka dapat disimpulkan terdapat hubungan antara strategi koping dan kesejahteraan psikologis pada remaja yang mengalami kekerasan dalam rumah tangga (KDRT). Hubungan antara kedua variabel memiliki kekuatan yang besar, sedangkan hubungan antara jenis strategi koping tertentu dengan variabel kesejahteraan psikologis memiliki kekuatan hubungan dengan rentang kecil dan besar. Hal ini menandakan semakin tinggi penggunaan strategi koping, maka semakin tinggi pula kesejahteraan psikologis yang akan dialami oleh remaja dalam konteks kekerasan dalam rumah tangga (KDRT).

Saran untuk penelitian selanjutnya adalah mencari tahu besar pengaruh tiap variabel terhadap kesejahteraan psikologis remaja. Bagi remaja diharapkan dapat melakukan upaya-upaya yang dapat membantunya untuk mengatasi masalah kekerasan dalam rumah tangga (KDRT) dengan strategistrategi koping yang adaptif atau fungsional dengan mempertimbangankan sumber daya yang dimiliki dan tidak melakukan upaya-upaya penyelesaian masalah yang destruktif atau mengarah ke perbuatan negatif seperti penggunaan alkohol atau minuman keras, sehingga dapat memperoleh kesejahteraan psikologis yang baik dalam jangka panjang. 


\section{UCAPAN TERIMAKASIH}

Peneliti ingin mengucapkan terimakasih pada seluruh pihak yang terlibat dan membantu dalam pelaksanaan penelitian ini. Terimakasih untuk seluruh dosen pengajar dan staff Fakultas Psikologi Universitas Airlangga, partisipan penelitian, teman-teman peneliti, dan seluruh pihak yan tidak bisa disebutkan satu persatu.

\section{DEKLARASI POTENSI TERJADINYA KONFLIK KEPENTINGAN}

Tazakka Putri Oktoji \& Herdina Indrijati tidak bekerja, menjadi konsultan, memiliki saham, atau menerima dana dari perusahaan atau organisasi manapun yang mungkin akan mengambil untung dari diterbitkannya naskah ini.

\section{PUSTAKA ACUAN}

Azhari, D. A. (2019). HUBUNGAN ANTARA SELF-COMPASSION DENGAN PSYCHOLOGICAL WELL-BEING PADA REMAJA. UNIVERSITAS AIRLANGGA.

Carver, C. S. (1997). You want to measure coping but your protocol's too long: Consider the brief COPE. International Journal of Behavioral Medicine, 4(1), 92-100.

Carver, C. S., Scheier, M. F., \& Weintraub, K. J. (1989). Assessing Coping Strategies: A Theoretically Based Approach. Journal of Personality and Social Psychology, 56(2), 267-283. https://doi.org/10.1037/0022-3514.56.2.267

Cynthia, U. N., Chukwudum, A. N., Chukwuma, Arinze, O. C., \& Chukwukeluo, C. B. (2018). Relationship between Psychological Wellbeing and Domestic Violence among Adolescents Home Caregivers and Non-Home Caregivers in Nigeria. Journal of Psychology \& Psychotherapy, 08(02). https://doi.org/10.4172/2161-0487.1000340

Freire, C., Ferradás, M. D. M., Valle, A., Núñez, J. C., \& Vallejo, G. (2016). Profiles of psychological wellbeing and coping strategies among university students. Frontiers in Psychology, 7(OCT), 1-11. https://doi.org/10.3389/fpsyg.2016.01554

Gao, J., \& McLellan, R. (2018). Using Ryff's scales of psychological well-being in adolescents in mainland China. BMC Psychology, 6(1), 1-8. https://doi.org/10.1186/s40359-018-0231-6

Lazarus, R. S., \& Folkman, S. (1984). Stress, appraisal, and coping. Springer Publishing Company, Inc.

M.Senthil, Vidyarthi, S., \& Kiran, D. M. (2014). Family and Mental Illness. IOSR Journal of Humanities and Social Science, 19(10), 32-37. https://doi.org/10.9790/0837-191033237

Mayordomo-Rodríguez, T., Meléndez-Moral, J. C., Viguer-Segui, P., \& Sales-Galán, A. (2015). Coping Strategies as Predictors of Well-Being in Youth Adult. Social Indicators Research, 122(2), 479-489. https://doi.org/10.1007/s11205-014-0689-4

Monzani, D., Steca, P., Greco, A., D’Addario, M., Cappelletti, E., \& Pancani, L. (2015). The situational

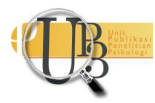


version of the brief COPE: Dimensionality and relationships with goal-related variables. Europe's Journal of Psychology, 11(2), 295-310. https://doi.org/10.5964/ejop.v11i2.935

Moreno, C. G., Jansen, H. A., Ellsberg, M., Heise, L., \& Watts, C. H. (2006). Prevalence of intimate partner violence: fi ndings from the WHO multi-country study on women's health and domestic violence. WHO Multi-Country Study on Women's Health and Domestic Violence against Women Study Team, Vol 368(2). https://doi.org/10.22452/mjs.vol28no2.10

Nastasi, B. K., \& Borja, A. P. (2016). International Handbook of Psychological Well-Being in Children and Adolescent (B. K. Nastasi \& A. P. Borja (eds.)). Springer.

Papalia, D. E., Olds, S. W., \& Feldman, R. D. (2009). Human Development (11th ed.). McGraw-Hill. http://hdr.undp.org/en/data

Rode, D., Rode, M., Marganski, A. J., \& Januszek, M. (2019). The Impact of Physical Abuse \& Exposure to Parental IPV on Young Adolescents in Poland: a Clinical Assessment and Comparison of Psychological Outcomes. Journal of Family Violence, 34(5), 435-447. https://doi.org/10.1007/s10896-019-00036-4

Ryan, R. M., \& Deci, E. L. (2001). On happiness and human potentials: A review of research on hedonic and eudaimonic well-being. Annual Review of Psychology, 52, 141-166. https://doi.org/10.1146/annurev.psych.52.1.141

Ryff, C. D. (1989). Happiness is everything, or is it? Explorations on the meaning of psychological wellbeing. Journal of Personality and Social Psychology, 57(6), 1069-1081. https://doi.org/10.1037/0022-3514.57.6.1069

Ryff, C. D., \& Singerb, B. (1996). Psychological Well-Being: Meaning, Measurement, and Implications for Psychotherapy Research Key Words Self-acceptance Purpose in life Positive relationships Personal growth Autonomy Environmental mastery Sociodemographic differences Vulnerability Resilien. Psychother Psychosom, 65, 14-23. https://www.karger.com/Article/PDF/289026

Santrock, J. W. (2014). ADOLESCENCE (15th ed.). McGraw-Hill Education.

Zafirah, S. B., \& Indriana, Y. (2016). Strategi Koping Korban Kekerasan Dalam Rumah Tangga (KDRT). Jurnal Empati, 5(April), 229-235. 